G. VANCSÓ

S, PEKKER

0 . EGYED

A. JANOSSY
CIS-TRANS ISOMERIZATION OF POLYACETYLENE INDUCED BY MECHANICAL ROLLING
Hungarian Academy of Sciences

\section{CENTRAL}

RESEARCH

INSTITUTE FOR

PHYSICS 


\title{
CIS-TRANS ISOMERIZATION OF POLYACETYLENE INDUCED BY MECHANICAL ROLLING
}

\author{
G. Vancsó*, S. Pekker, O. Egyed* and A. Jánossy \\ Central Research Institute for Physics \\ H-1525 Budapest 114, P.O.B. 49, Hungary \\ *Central Research Institute for Chemistry of the \\ Hungarian Academy of Sciences \\ H-1525 Budapest, P.O.B. 17, Hungary
}




\section{ABSTRACT}

The influence of mechanical rolling on the ESR spectrum of originally cis-rich polyacetylene is investigated. Rolling decreases the peak-to-peak ESR linewidth, $\Delta \mathrm{H}_{\mathrm{pp}}$. This phenomenon is supposed as being related to cistrans isomerization. However, rolling increases only slightly the trans content and the spin susceptibility of the polymer. These observations can be explained by assujing that the rolling induced isomerization preferentially increases the length of the trans segments with unpaired spins. Rolling is less effective than heating in giving rise to isomerization within all-cis segments or in lengthening trans segments with no stable unpaired spins. The behaviour of $\Delta \mathrm{H}_{\mathrm{pp}}$ as a function of trans content in the case of rolling induced isomerization is different from the thermally activated process. The ESR linewidth gives information only about the "trans macroradicals" and not about the total cistrans isomer ratio, that used to be employed.

\section{АННОТАЦИЯ}

Исследуется влияние механической прокатки на эпр спектр полиацетилена, ( $\mathrm{CH}$, который в начале существует в цис-изомерной форме. Прокатка вызывает снижение ширины ЭПР синглета. Это явление можно связать с цис-транс изомеризацией. Содержание транс-изомера и спин восприимчивость полимера только слабо возрастают под действием прокатки. Мы предполагаем, что изомеризация, вызванная прокаткой, удлиняет, в первую очередь, сегменты в форме транса, имеющие непарные спины. Процессы, в которых длина транс-сегментов без неспаренного электрона увеличивается или инициируются новые транс-сегменты, протекают лишь с малой вероятностью. Ширина ЭПР линии полимера, как функция транс-содержания, в случае изомеризации, вызыванной прокаткой, отличается от ширины, получаемой в $(\mathrm{CH})$, изомеризованном термическим способом. В конечном итоге ширина ЭПр линии здёсь дает информацию только о характере транс-полиенил макрорадикалов и не дает сведений о других полиенах.

\section{KIVONAT}

A mechanikai hengerlésnek a cisz poliacetilén ESR spektrumára gyakorolt hatását vizsgáltuk. A hengerlés a szinglett ESR jel szélességének a csökkenését okozza. A jelenséget cisz-transz izomerizációval hozzuk kapcsolatba. A hengerlés hatására a transz tartalom és a spin szuszceptibilitás csak gyengén nỗ. Ennek oka, hogy feltételezésünk szerint a hengerléssel elôidézett izomerizáció elsôsorban a párositatlan spineket tartalmazó transz szegmensek hosszát növeli. A hengerlés hatására cisz-transz izomerizáció iniciálása illetve stabil párositatlan elektront nem tartalmazó transz szegmens hosszának növekedése - a termikus izomerizációval ellentétben - lényegesen kisebb valószinüségü. Az ESR jel szélessége mint a transz tartalom függvénye a termikusan aktivált illetve a hengerlés hatására bekövetkezô izomerizáció esetén eltérố jellegủ. Az ESR jel szélessége csak a transz módosulatu polienil makrogyökökrôl ad információt és nem hozható kapcsolatba a diamágneses poliénekkel. 
INTRODUCTION

Polyacetylene (polyvinylene, hereinafter denoted as $(\mathrm{CH})_{x}$ ) has recently been the subject of a large number of experimental and theoretical studies $[1,2$ and references therein] because of its remarkable electrical, magnetic and other interesting properties. The most unusual property of this polymer is that its electrical conductivity can be varied over twelve orders of magnitude on doping with different donors or acceptors $[3]$.

Polyacetylene consists of a random accumulation of highly crystalline fibres with a diameter in the order of $20 \mathrm{~nm}$ [4]. $\mathrm{X}$-ray measurements suggest strongly that the molecular chains are parallel to the fibre axis [5]. The fibres occupy only a fraction of the total volume, therefore the virtual density determined from the mass and dimensions is $1 / 4-1 / 2$ of the real value, $1.16 \mathrm{~g} / \mathrm{cm}^{3}$ according to flotation measurements [6].

There exist $\mathrm{cis}$ and trans isomer forms of $(\mathrm{CH})_{\mathrm{x}}$ chains $[7,8,9]$. The two possible cis skeletons are the trans-cisoid and the cis-transoid. According to the calculations of Yamabe et al. [8] the trans-cisoid form is less stable than the cistransoid. The polymerization of acetylene in the presence of a Ziegler-type catalyst primarily yields polymer in the configuration which can be isomerized into all-trans by heating $[10,11]$.

Bond alternation is present in the polymer which thus reduces its energy compared with the uniform chain [12]. During the cis-trans isomerization neutral defects are formed in the bond alternation [13]. In these defects the phase of bond alternation changes by $180^{\circ}$. This means that the "single" and "double" bonds are shifted by one carbon-carbon distance and one unpaired electron is left behind. These unpaired electrons are responsible for the paramagnetic properties of polyacetylene [14].

It was pointed out by Bernier et al. that such defects exist only in all-trans segments $[15,16]$. The two sides of a trans isomer chain separated by this defect have equal energy 
in a structure unit, hence the spin can be shifted without any change of energy. This is in accordance with the "motionally narrowed" ESR line observed in this case [14]. On a cis backbone a shift in the bond alternation changes the symmetry and hence the energy of the chain. (For example, a cis-transoid structure would turn into a trans-cisoid one). For this reason mobile spins cannot exist in a cis segment. The relative1y broad EsR signal observed in cis-rich samples is attributed to short trans segments with an unpaired spin. Thus, the ESR signal in polyacetylene yields information only about the al1-trans polyenyl radicals.

During heat-induced isomerization, as the trans content increases, the spin susceptibility $x_{p}$ also increases, while the ESR linewidth decreases $[11,13]$. This is interpreted as an increase of both the number and mean length of the trans segments. Isomerization of a few per cent was also observed after stretching the cis-rich samples by mechanical elongation [17]. It was shown by proton NMR measurements that mechanical rolling also caused partial isomerization [18].

In order to make clear the influence of the mechanical rolling on the trans polyenyl radical structure we have investigated the ESR spectra and the cis-trans composition of originally cis-rich polyacetylene films before and after rolling.

\section{EXPERIMENTAL}

Polyacetylene films were synthesized by the method developed by Ito et al. [4], using $\mathrm{Ti}(\mathrm{O}-\mathrm{n}-\mathrm{Bu})_{4}-\mathrm{AlEt_{3 }}$ homogeneous catalytic system in toluene solution. Polymerization was performed at $-78^{\circ} \mathrm{C}$ in order to obtain a cis-rich isomer. The samples used in this study were cut from flexible, shiny foils of 20-100 $\mu \mathrm{m}$ in thickness.

The isomer content of the samples was determined from their infrared spectra according to Ito et al. [4] using the trans $\mathrm{C}-\mathrm{H}$ and $\mathrm{cis} \mathrm{C}-\mathrm{H}$ out-of-plane deformation bands at $1015 \mathrm{~cm}^{-1}$ and $740 \mathrm{~cm}^{-1}$, respectively. The cis content of poly- 
acetylene was calculated by the formula:

$$
\text { cis cont. }[\%]=100\left[1.30 A_{\text {cis }} /\left(1.30 A_{\text {cis }}+A_{\text {trans }}\right)\right]
$$

where $A_{\text {Cis }}$ and $A_{\text {trans }}$ are the absorbances at the above frequencies.

The absorption IR spectra were recorded on a NICOLET

7199 FT-IR spectrometer. The number of scans was at least 200.

The $A_{\text {Cis }}$ values of cis-rich polymers were very high. The IR spectra could be evaluated when the effective surface density of $(\mathrm{CH})_{\mathrm{X}}$ films was about $1.5 \times 10^{-3} \mathrm{~g} / \mathrm{cm}^{2}$. This means that unrolled foils 20-25 $\mathrm{m}$ in thickness had to be used. In this case $A_{C i s}$ was in the order of 2.5 and the corresponding $A_{\text {trans }}$ was about 0.3 .

Whereas A trans could be measured precisely, the high $A_{\text {cis }}$ absorbances may be distorted substantially due to the stray light arising from imperfections of the sample. This may lead to an overestimation of the real trans content.

The films had an initial cis content of $90-92 \%$. Their bulk density determined from the mass and dimensions was $0.65 \pm 0.05 \mathrm{~g} / \mathrm{cm}^{3}$ and $1.14 \pm 0.01 \mathrm{~g} / \mathrm{cm}^{3}$ as obtained from the flotation measurements which were performed in a density gradient column containing toluene and carbon tetrachloride. The samples were kept under vacuum at dry ice temperature before the measurements.

ESR spectra were investigated using a JEOL-FE3X spectrometer working in the $\mathrm{X}$-band. $\mathrm{Mn}^{++}-\mathrm{MgO}$ powder was utilized as a reference signal and VARIAN standard containing $3.0 \times 10^{15}$ spins/cm for the spin density measurements. All measurements were carried out at room temperature and in vacuo of better than 1 torr.

The as-prepared $(\mathrm{CH})_{x}$ films were rolled using an electric rolling device with controlled gap between its two chromecovered cylinders. The gap was decreased in $10 \mu \mathrm{m}$ steps and the samples were rolled several times. This procedure was carried out in the atmosphere at room temperature. The mean thickness before $\left(d_{0}\right)$ and after $\left(d_{i}\right)$ rolling was determined 
from at least 15 measured data. We used the reduced thickness - $d_{i} / d_{0}[\%]$ - to characterize the thinning.

The samples were exposed uniformly to air for 15-20 minutes, and then put into ESR tubes and evacuated.

\section{RESULTS}

In Fig.1 the bulk density of the samples is plotted as a function of the reduced thickness, $d_{i} / d_{0}$. After thinning the polymer films to a $\left(d_{i} / d_{0}\right)_{l}$ of ca. $50 \%$, their bulk density reaches the fibre density $\left(1.14 \mathrm{~g} / \mathrm{cm}^{3}\right)$. Up to this point the pores between the $(\mathrm{CH})_{x}$ fibres vanish due to the rolling. Near this $\left(d_{i} / d_{0}\right) l$ value the films become compact and hard. As expected, the fibre density from flotation measurements remains constant during the rolling.

The ESR peak-to-peak linewidths and the cis-trans composition obtained from the IR spectra are shown in Fig. 2 as a function of reduced thickness, $d_{i} / d_{0}$. ESR measurements were also performed on the same batch of samples on wich the IR spectra were recorded. The ESR linewidths of these samples are marked in Fig.2. As can be seen from this figure, $\Delta H_{p p}$ remains constant until the bulk density of $(\mathrm{CH})_{x}$ reaches the density of the fibres. As the samples are thinned further, $\Delta \mathrm{H}_{\mathrm{pp}}$ begins to decrease.

Shirakawa and coworkers reported ESR linewidth data as a function of the trans content of $(\mathrm{CH})_{x}[11]$. For the experiments they used polymers obtained by thermal cis-trans isomerization of a cis-rich $\left(\mathrm{CF}_{i}\right)_{\mathrm{x}}$. According to their data the decrease in $\Delta H_{p p}$ is connected with an increase in trans content. Shirakawa's results are plotted in Fig. 3 together with our data. It can be seen that in rolled samples $\Delta H_{p p}$ rapidly decreases as a function of the trans content in contrast to thermal isomerization. The trans content of the rolled sample with a linewidth of $4.7 \times 10^{-4}$ Tesla ( 4.7 Gauss) was found to be less than $14 \%$ whereas in the case of the heated samples of Shirakawa a trans content of $32-46 \%$ corresponds to this linewidth. 
The initial $\Delta \mathrm{H}_{\mathrm{pp}}$ of cis-rich samples is obviously a function of preparation. As mentioned above, the $\Delta \mathrm{H}_{\mathrm{pp}}$ of cisrich samples is determined by the mean conjugation length of trans polyenyl-radicals. Thus the discrepancy in the magnitude of $\Delta \mathrm{H}_{\mathrm{pp}}$ between our and Shirakawa's data is here a question of minor importance, and it is probably due to the difference in conjugation length of "macroradicals" in the initial samples.

Exposure of $(\mathrm{CH})_{x}$ to air increases the $\Delta \mathrm{H}_{\mathrm{pp}}$ of both the cis [19] and the all trans [20] isomers. The ESR linewidths of the rolled samples after a $30 \mathrm{~min}$. heat treatment at $180^{\circ} \mathrm{C}$ decreased to $7 \times 10^{-5}$ Tesla (0.7 Gauss). This residual linewidth is rather small and shows that the exposure of the samples to air for a short period has only a small influence on the results.

The spin susceptibility $x_{p}$ of the samples was also measured as a function of $d_{i} / d_{0}$. The results are shown in Fig. 4 . The spin susceptibility as a function of thinning remains constant within the experimental error of $\pm 15 \%$.

\section{DISCUSSION}

We focus on the explanation of the observed rapid decrease in $\Delta \mathrm{H}_{\mathrm{pp}}$ following the thinning of $(\mathrm{CH})_{\mathrm{x}}$ whereas only a slight increase in the trans content and in $x_{p}$ was measured.

It was mentioned that the unpaired electrons in $(\mathrm{CH})_{x}$ are related to trans segments. The magnitude of $\Delta H_{p p}$ of cis-rich polymer is determined by the mean delocalization length of the spin [21] (i.e., by the mean length of trans segments with unpaired electrons). Thus any change in $\Delta H_{p p}$ should above all indicate a change in the mean conjugation length of polyenyl radicals. The conjugation length $n$ of polyenyl "macroradicals" (the number of $-\mathrm{CH}=\mathrm{CH}-$ units) and $\Delta \mathrm{H}_{\mathrm{pp}}$ are related [21]:

$$
\Delta H_{p p} \propto n^{-\frac{1}{2}}
$$

This relationship should be approximately valid if $\Delta H_{p p}$ is controlled by the unresolved hyperfine structure of fixed spins 
and surrounding protons. It may be supposed that in cis-rich $(\mathrm{CH})_{x}$ the trans segments are not long enough to allow spin diffusion since delocalization of the defects is expected to extend to several $\mathrm{CH}$ units $[14,22]$. Therefore in such case a motionally narrowed ESR line cannot form. This assumption is also supported by dynamic nuclear polyrization measurements [23].

We explain the observed decrease in ESR linewidth by the extension of the length of trans segments with unpaired spins. Using relationship (2) a decrease in $\Delta \mathrm{H}_{\mathrm{pp}}$ from $8 \times 10^{-4}$ Tesla to $5.5 \times 10^{-4}$ Tesla would indicate a twofold increase in the mean length of trans polyenyl "macroradicals". The initial spin concentration is of the order of $5 \times 10^{-5}$ spins/CH unit and the corresponding mean radical length using Ohnishi's results [21] was estimated to be near $20(\mathrm{CH})_{2}$ units. An increase of the length of radical segments by a factor of 2 in itself gives rise to a negligible increase of the trans content. The lack of variation of $x_{s}$ together with the small increase of the trans component shows that relatively few "new" trans segments are formed. This may be contrasted to the isomerization by heat treatment investigated by Shirakawa et al.[11] (see Fig.3). For isomerization by heat treatment the linewidth decreases less rapidly with trans content and there is a substantial increase in $x_{p}$ also $[11,13]$. Thus for this case also "new" trans segments are initiated.

The growth of the polyenyl radicals during the rolling begins when the films are thinned below $d_{i} / d_{0}$ of ca. $50 \%$ (i.e. when the pores between the $(\mathrm{CH})_{x}$ fibres are removed). On further thinning, the length of the samples along the direction of the rolling increases. Parallel with the lengthening of $(\mathrm{CH}) x$ films there is a possibility that the fibres become aligned and the chain segments become ordered via bond rotation.

Cis-trans isomerization takes place in the presence of unpaired spins on the rotating bonds [13,24]. The cis-trans "border" can thus shift thereby decreasing the cis part of 
the chain in the presence of an unpaired spin with a small energy compared with a "border" with no unpaired spins. In this case the isomerization is related to a rotation of C-C single bonds [24]. The phenomenon is illustrated in Fig.5. Rolling maintains the spin concentration but extends the length of the trans radicals and thus slightly isomerizes polyacetylene. The observed spins were presumably formed by the heat induced isomerization which took place when the temperature first rose from $-78^{\circ} \mathrm{C}$ to room temperature.

ACKNOWLEDGEMENT

One of us (G.V.) wishes to express his indebtedness to Drs. A.Rockenbauer, B.Turcsányi, T.T.Nagy and G.Jalsovszky for many useful discussions. 
REFERENCES

[1] MacDiarmid, A.G., Heeger, A.J.: Synthetic Metals 1, 101 (1980)

[2] MacDiarmid, A.G., Heeger, A.J.: Molecular Metals, ed. Hatfield, W.E., Plenum, New York, 1979, p.161

[3] Chiang, C.K., Fincher, C.R., Park, Y.W., Heeger, A.J., Shirakawa, H., Louis, E.J., Gau, S.C., MacDiarmid, A.G.: Phys. Rev. Lett. 39, 1098 (1977)

[4] Ito, T., Shirakawa, H., Ikeda, S.: J. Polym. Sci. Polym. Chem. Ed. 12, 11 (1974)

[5] Akaishi, T., Miyasaka, K., Ishikawa, K., Shirakawa, H., Ikeda, S.: J. Polym. Sci. Polym. Phys. Ed. 18, 745 (1980)

[6] Baughman, R.H., Hsu, S.L., Pez, G.P., Signorelli, A.J.: J. Chem. Phys. 68, 5405 (1978)

[7] Shirakawa, H., Ikeda, S.: Polym. J. 2, 231 (1971)

[8] Yamabe, T., Tanaka, K., Terama-e, H., Fukui, K.: Solid State Comm. 29, 329 (1979)

[9] Karpfen, A., Petkov, J.: Solid State Comm. 29, 251 (1979)

[10] Ito, T., Shirakawa, H., Ikeda, S.: J. Polym. Sci. Polym. Chem. Ed. 13, 1943 (1975)

[11] Shirakawa, H., Ito, T., Ikeda, S.: Makromol. Chem. 179, 1565 (1978)

[12] Kertész, M., Koller, J., Azman, A.: J. Chem. Phys. 67, 1180 (1977) and references therein

[13] Chien, J.C.W., Karasz, F.E., Wnek, G.E.: Nature 285, 390 (1980)

[14] Goldberg, I.B., Crowe, H.R., Newman, P.R., Heeger, A.J., MacDiarmid, A.G.: J. Chem. Phys. 70, 1132 (1979)

[15] Bernier, P., Rolland, M., Linaya, C., Disi, M.: Polymer 21,7 (1980)

[16] Bernier, P., Rolland, M., Linaya, C., Disi, M., Sledz,J., Schue, F., Fabre, J.M., Giral, L.: preprint, to be published in Polym. J. (1981)

[17] Shirakawa, H., Ikeda, S.: Synthetic Metals 1, 175 (1979/80)

[18] Devreux, F., Dôry, I., Mihály, L., Pekker, S., Jánossy, A., Kertész, M.: to be published in J. Polym. Sci. Polym. Phys. Ed. 
[19] Vancsó, G., Rockenbauer, A.: to be published in Chemica Scripta (1981)

[20] Holczer, K., Boucher, J.P., Devreux, F., Nechtschein, M.: Phys. Rev. B. 23, 1051 (1981)

[21] Ohnishi, S.I., Ikeda, Y., Sugimoto, S.I., Nitta, I.: J. Polym. Sci. 47, 503 (1960)

[22] Rice, M.J.: Phys. Lett. 71A, 152 (1979)

[23] Nechtschein, M., Devreux, F., Greene, R.L., Clarke, T.C., Street, G.B.: Phys. Rev. Lett. $\underline{44}, 356$ (1980)

[24] Pekker, S. et al.: to be published 


\section{FIGURE CAPTIONS}

Fig.1. Density vs. reduced thickness for $(\mathrm{CH})_{\mathrm{x}}$ films. ( o ) data obtained from mass and dimensions ( ) data obtained from flotation measurements

Fig.2. ESR peak-to-peak linewidth and cis content as a function of reduced thickness. Isomer content was measured on samples marked with $(\Delta)$.

Fig.3. ESR peak-to-peak linewidth vs. trans content $(x)$ data from [11] measured in heat treated samples ( o ) our data measured in rolled samples $(\Delta)$ our result obtained in a sample completely isomerized by heating.

Fig.4. Spin density vs. reduced thickness.

Fig.5. Idealized, schematic illustration of proposed mechanism of cis-trans isomerization. The plane of the cis segment, $s_{2}$ is perpendicular to that of the trans, $\mathbf{S}_{1}$. In the next "step" of isomerization due to the marked bond rehybridization, the unpaired electron shifts to the $C$ atom labelled "A" and the $C$ atom labelled "B" transfers to plane $\mathrm{S}_{1}$. 


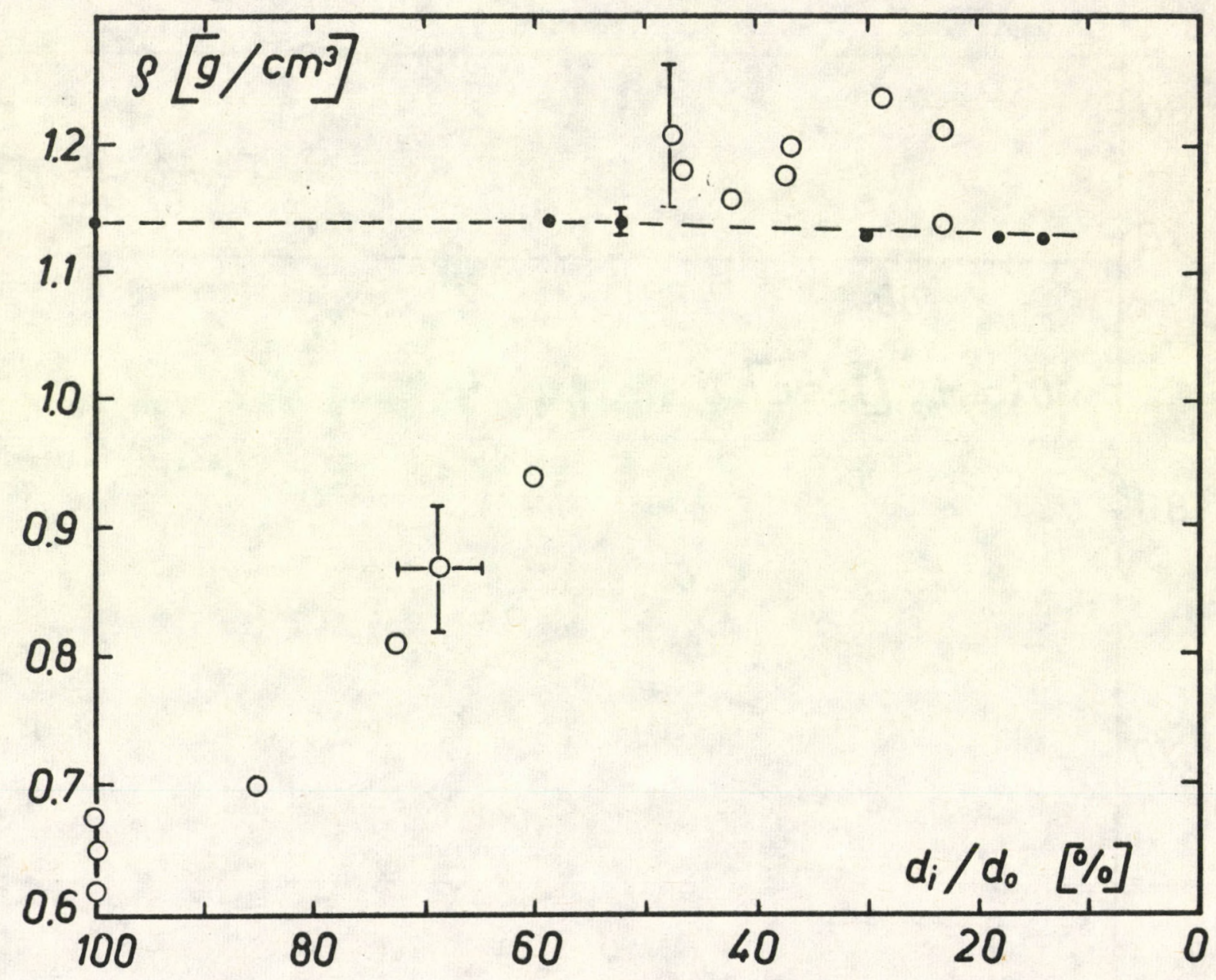

Fig. 1 


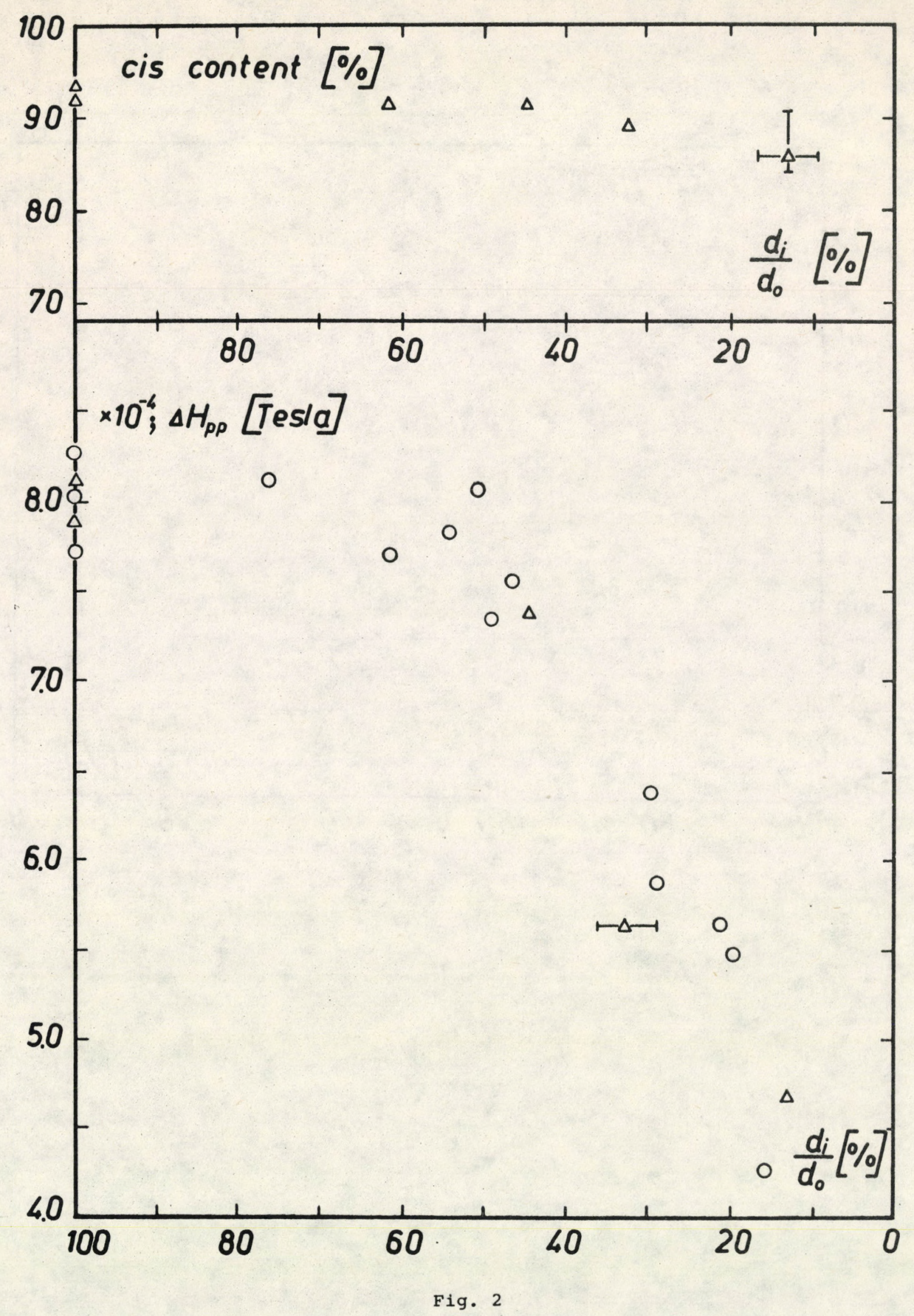




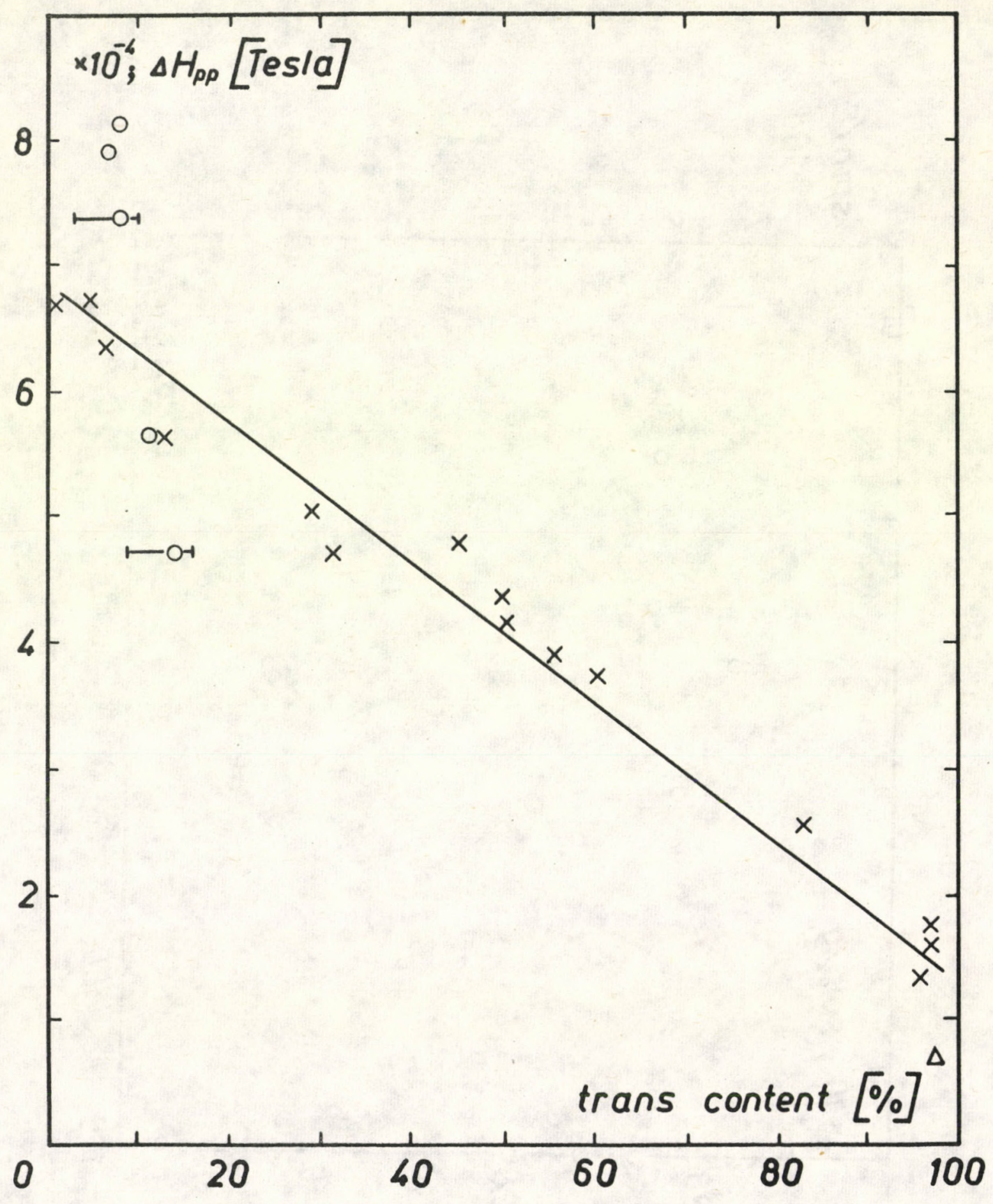

Fig. 3 


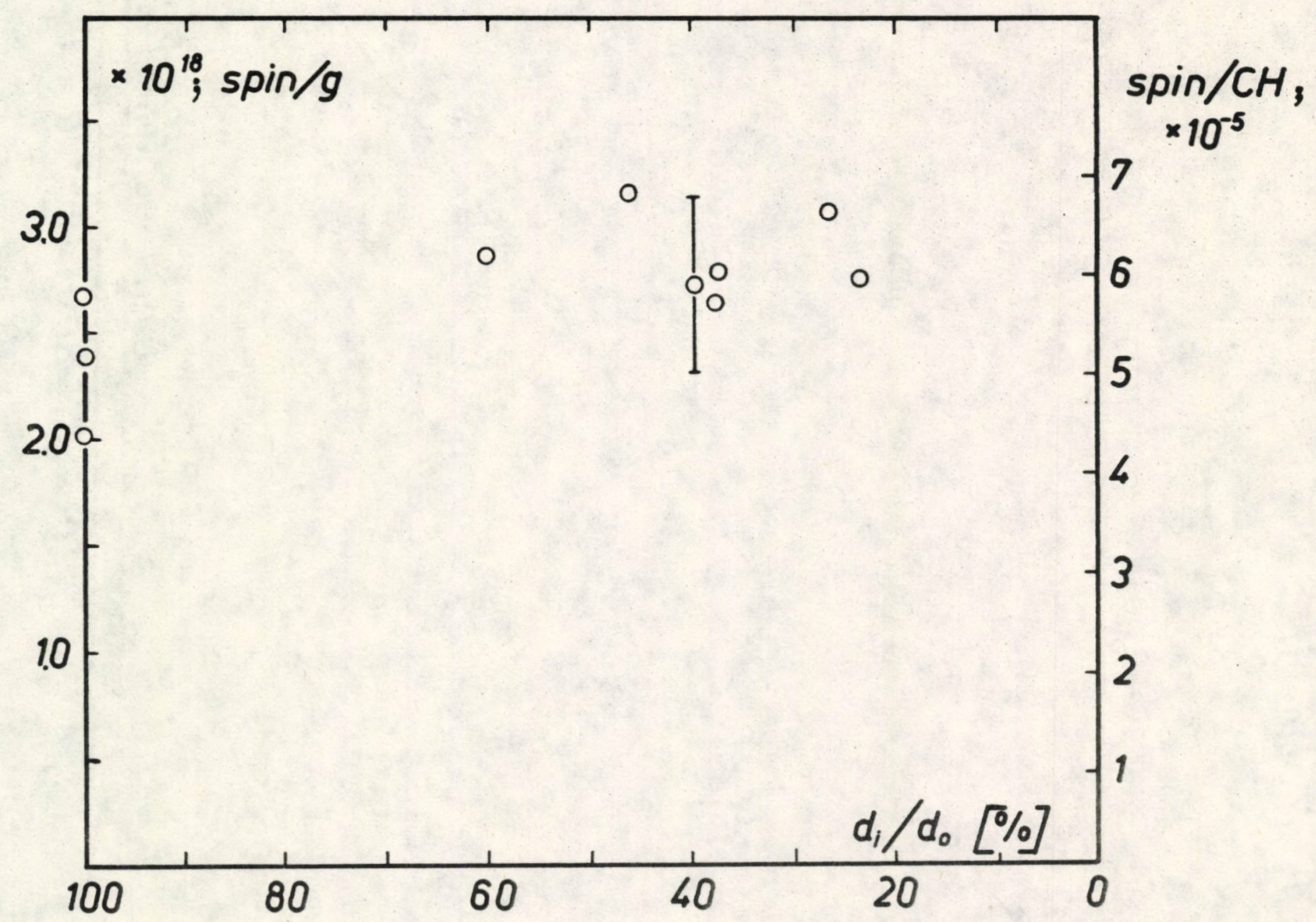

Fig. 4 


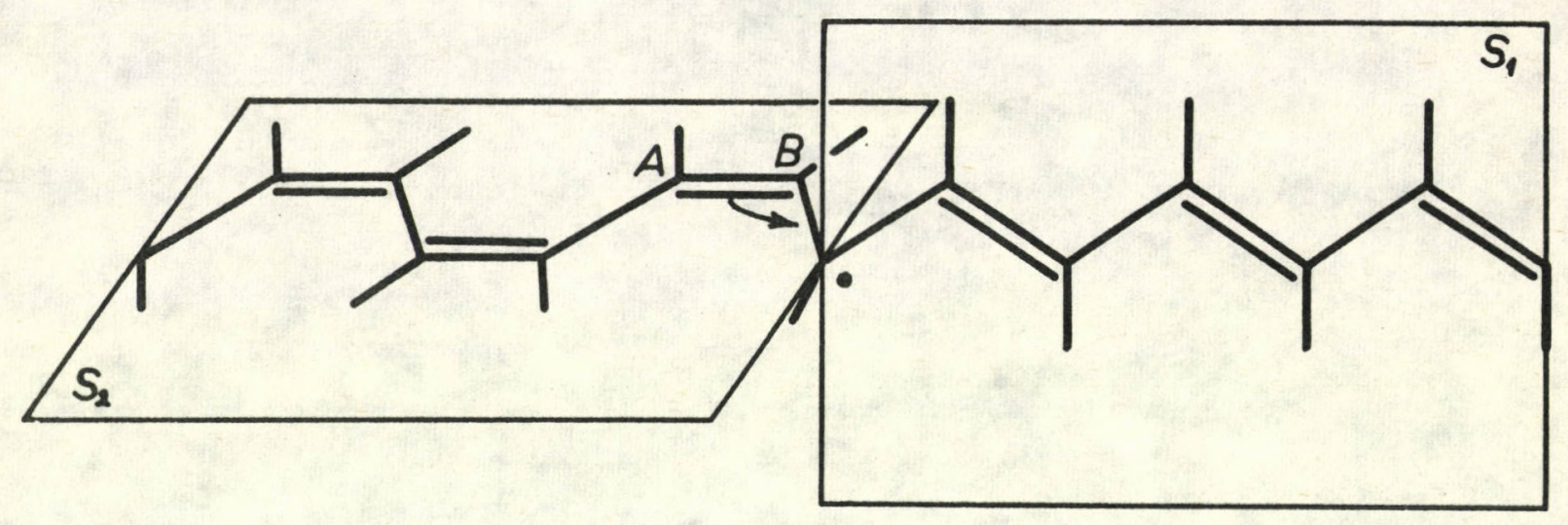

Fig. 5 




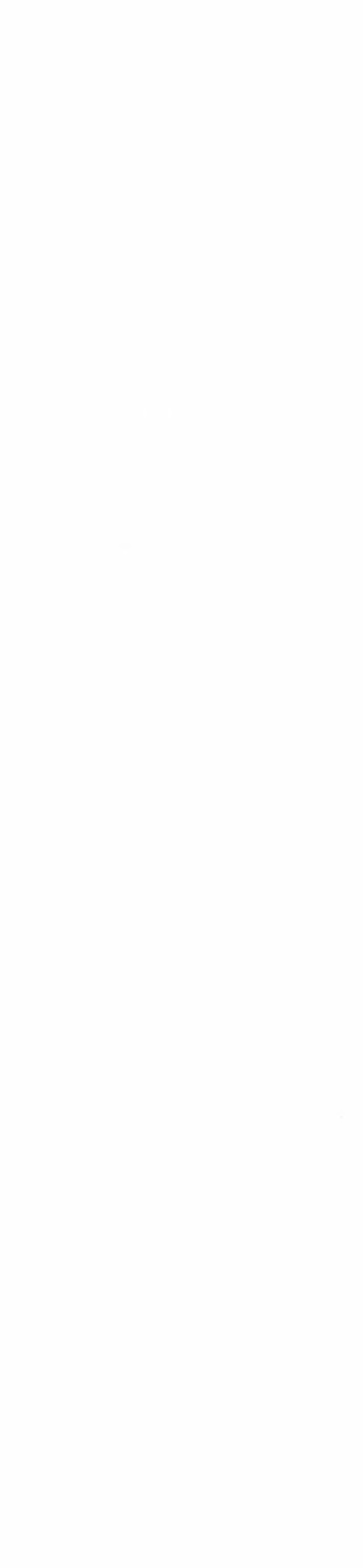


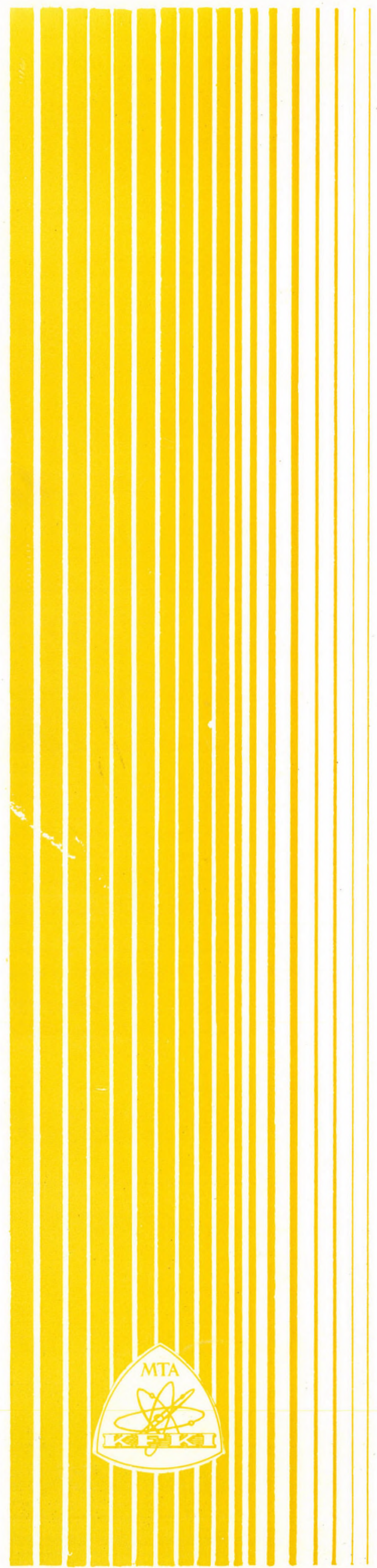

Kiadja a Központi Fizikai Kutató Intézet Felelôs kiadó: Kroó Norbert

Szakmai lektor: Holczer Károly

Nyelvi lektor: Harvey Shenker

példányszám: 520 Törzsszám: 81-361

Készült a KFKI sokszorositó ủzemében

Felelõs vezetô: Nagy Károly

Budapest, 1981. junius hó 